\title{
ANALISIS KARAKTER GEMAR MEMBACA SISWA SMP NEGERI 30 MUARO JAMBI
}

\author{
${ }^{1}$ Wittentirelli, ${ }^{2}$ Archi Herman Saputra, ${ }^{3}$ Aulia Eka Putra \\ ${ }^{1}$ Kepala Sekolah SMA Negeri 11 Tebo \\ ${ }^{2,3}$ Universitas Negeri Jambi
}

Email: ${ }^{1}$ wittentirelli@gmail.com, ${ }^{2}$ archihermansaputra100@gmail.com, 3auliaekaputraaa@gmail.com

\section{Tersedia Online di \\ http://www.jurnal.unublitar.ac.id/ index.php/briliant}

Sejarah Artikel

Diterima pada 23 April 2019

Disetuji pada 29 April 2019

Dipublikasikan pada 22 Mei 2019

Hal. 182-188

\section{Kata Kunci:}

Gemar membaca, karakter, siswa

\section{DOI:}

http://dx.doi.org/10.28926/briliant .v3i4.305

\begin{abstract}
Abstrak: Membaca merupakan suatu hal yang sangat penting dalam kegiatan belajar siswa. Kegiatan gemar membaca perlu ditingkatkan agar terciptanya pelajar yang berkualitas dan berdedikasi tinggi.. Penelitian ini dilakukan untuk mengetahui bagaimana tingkat gemar membaca siswa SMP Negeri 30 Muaro Jambi.Kami menggunakan metode mixed method dimana kami menggunakan sebuah angkaet yang didalamnya terdapat sebuah pernyataan yang nantinya siswa dituntut untuk memilih jawaban yang tersedia seperti sangat baik, baik, kurang baik dan tidak baik. Dari hasil data kami membuat rata-rata kelas VIIC dan IX A dan didapatkan hasil rata-ratanya yaitu 79 dan 78. Dari Hasil tersebut kami menyimpulkan hampir semua siswa gemar membaca.
\end{abstract}

\section{PENDAHULUAN}

Pendidikan adalah suatu usaha secara disengaja untuk mempersiapkan anak didik dengan menumbuhkan kekuatan kepribadiannya (Sasono, 1998:122). Dalam menumbuhkan kepribadian suatu anak diawali dengan dilingkungan keluarganya. Pendidikan tidak hanya didapat dari sekolah tetapi juga dapat didapatkan dimana saja dalam kehidupan sehari-hari. Karakter terbentuk tidak dari lahir melainkan terbentuk dari lingkungan ia tinggal. Lingkungan yang baik akan melahirkan karakter seseorang yang baik juga begitupun juga sebaliknya. Keluarga merupakan lingkungan yang sangat krusial dalam membentuk karakter anak. Dimana keluarga yang memiliki latar belakang yang baik akan menciptakan karakter yang baik pula bagi anak. Sikap dalam pembelajaran sangatlah penting, begitupun dengan sikapyang ada pada pembelajaran. Minat baca siswa yang cenderung rendah akan membuat sumberdaya manusia kedepannyab sangatlah kurang baik. Harapan yang semestinya untuk generasi selanjutnya sangatlah besar. Diiringi dengan banyaknya faktor yang mempengaruhi tinggi rendahnya tingkat minat baca siswa. Kegiatan membaca tidak hanya berkaitan dengan siswa disekolah melainkan juga dikalangan masyarakat kegiatan gemar membaca juga sangat dianjurkan. Menurut Safitri (2013 : 3) kegiatan membaca dilingkungan Tidak bisa dipungkiri membaca salah satu faktor agar seseorang lebih mengetahui baik sosial dan sains. 
Pendidikan karakter dapat disebut juga sebagai pendidikan moral, pendidikan nilai, pendidikan dunia afektif, pendidikan akhlak, atau pendidikan budi pekerti (Aeini, 2014 : 51).Pendidikan karakter bertujuan untuk menumbuhkan sikap atau perilaku yang baik dan juga bertanggung jawab. Menurunnya kualitas moral dalam kehidupan manusia Indonesia dewasa ini, terutama dikalangan siswa, menuntut diselenggarakannya pendidikan karakter (Sudrajat, 2011: 48). Karakter siswa yang saat ini sudah sangat menyimpang dimana masih banyaknya tindak kejahatan seperti kekerasan yang terjadi contohnya berantem disekolah, merokok, judi, bahkan ada yang berbuat asusila dengan kawan lawan jenisnya disekolah. Hal ini tentu sangat bobroknya karakter yang dimiliki siswa saat ini. Semakin majunya era globalisasi sampai saat ini pada era Revolusi Industri 4.0 dimana segala sesuatu hal dapat dilakukan dengan instan akan membuat siswa terbantu untuk mengakses informasi atau melakukan kegiatan sesuatu hal yang dapat dilakukan dengan bantuan digital. Makin maju teknologi tentu akan merubah karakter siswanya. Siswa yang dulunya buku merupakan sumber utama untuk mendapatkan informasi dan terlebih dahulu harus membacanya sekarang tidak perlu lagi untuk membaca dengan susah tinggal mencari langsung menggunakan internet. Kegiatan tersebut tentu mendapatkan siswa yang kecenderungan untuk malas membaca. Hal inilah perlu diterapkan system pendidikan karakter bagi siswa agar siswa tidak terjerumus kedalam dunia yang membuat dirinya malas untuk membaca.

Membaca merupakan suatu proses yang bersifat fisik dan psikologis, dimana maksud dari fisik merupakan kegiatan mengamati kegiatan visual dan merupakan proses mekanis dalam membaca (Darmadi: 21). Kegaiatan membaca merupakan hal utama bagi para siswa dalam menerima materi pembelajaran yang disampaikan oleh guru. Belajar tanpa membaca terlebih dahulu dibandingkan yang sudah membaca akan lebih mudah yang sudah membaca. Hal tersebut dikarenakan siswa akan lebih tahu materi apa yang hendak diajarakan nantinya oleh guru. Membaca tidak harus tentang materi pelajaran yang ada di sekolah saja melainkan dapat dilakukan dengan membaca buku yang lain seperti cerpen, majalah, novel dan lain-lain. Penelitian ini dilatarbelakangi karena membaca sebuah komponen sangat penting saat kegiatan proses belajar mengajar. Hal ini lah yang menjadi titik fokus kami untuk mengetahui bagaimana tingkat gemar membaca yang dimiliki siswa SMP Negeri 30 Muaro Jambi. Banyak hal yang menjadi acuan kami melakukan penelitian ini salah satunya dizaman yang penuh dengan ilmpu pengetahuan dan disertai dengan banyaknya teknologi canggih tentu akan mempengaruhi karakter seorang siswa. Dimana masih terdapat siswa yang lebih memilih cara yang instan memperoleh informasi dibandingkan dengan mencari informasi tersebut dengan sesksama. Rumusan masalah yang dapat kami teliti diantaranya apakah siswa saat ini masih gemar membaca. Dikarenakan era yang saat ini sangat memungkinkan siswa cenderung malas dalam membaca. Kami menitikberatkan penelitian ini untuk mengetahui seberapa tingginya minat baca atau gemar membaca siswa SMP Negeri 30 Muaro Jambi.

Suharmono (2015: 86) menyatakan bahwa upaya dalam meningkatkan minat baca masyarakat tidak dapat dibebankan pada keluarga saja, masyarakat, saja atau lembaga pendidikan saja, aspek keluarga, masyarakat, dan lembaga pendidikan mempunyai peran pentingdalam meningkatkan minat baca masyarakat. Dalam mengantisipasi siswa yang kurang gemar membaca ini 
merupakan sustu hal yang sangat penting. Di dalam kehidupan sehari-harinya siswa seharusnya dibekali dengan pemahaman tentang pentingnya kegiatan membaca. Membaca merupakan gerbang dari segala informasi bagi sesorang untuk mengetahui segala sesuatu. Lingkungan sekolah merupakan tempat yang paling pas dalam mewujudkan kegiatan gemar membaca siswa. Seperti yang di jelaskan Halidjah (2011:1-9) bahwasanya motivasi dibedakan atas dua macam yaitu intrinsik dan ekstrinsik. Maksud dari intrinsic yaitu motivasi yang berasal dari dalam pikiran siswa itu sendiri sedangkan kalau ekstrinsik bisa berasal dari luar siswa seperti lingkungan. Begitu juga peran guru juga dapat mengembangkan motivasi di dalam diri siswa. Namun tidak dipungkiri bahwa peran keluarga juga merupakan suatu hal yang juga penting dalam menumbuhkan siswa untuk gemar membaca. Biasanya orangtua selalu menyuruh anaknya untuk belajar setiap malam. Hal ini merupakan suatu cara agar siswa melakukan kegiatan membaca yang diiringi dengan kegiatan belajar. Dengan memberikan siswa tugas rumah seperti PR akan membuat siswa terpacu untuk dapat mengerjakan tuigas tersebut. Pada saat siswa mengerjakan tentu siswa akan terlebih dahulu membaca buku tersebut. Secara tidak langsung siswa akan melakukan kegiatan membaca berulang-ulang yangnantinya membuat siswa terbiasa akan hal membaca. Terdapat sekolah yang menerapkan sistem literasi dimana siswa terlebih dahulu membaca buku sebelum dilaksanakan kegiatan proses belajar mengajar. Hal ini juga merupakan salah satu solusi dalam meningkatkan gemar atau minat membaca bagi siswa. Harapan kami dari penelitian ini semoga kedepannya siswa akan lebih gmar dalam kegiatan membacanya.

\section{METODE}

Mixed method merupakan penelitian yang menggabungkan atau menggunakan penelitian kuantitatif dan kualitatif dalam satu proses penelitian (Yusuf., 2017 : 428). Penelitian kali ini kami menggunakan metode mixed method data kuantitatif dimana kami menggunakan sebuah angket dengan skala 1 . Maksud dari kata skala 1 adalah angket terdiri atas 1 lembar pernyataan dengan jumlah 25 penyataan berkaitan dengan kegiatan gemar membaca. Contoh salah satu pernyataannya yaitu siswa di suruh menjawab apakah mereka senang membaca buku dimanapun berada?. Selanjutnya Siswa dituntut memilih jawaban yang tertera dengan menceklis jawaban yang menurut mereka sesuai dengan pilihan jawabannya. Pilihan jawaban di simbolkan dengan SB,B,KB,TB, dimana maksud dari simbol tersebut adalah Sangat Baik, Baik, Kurang Baik, dan Tidak baik. Waktu yang diperlukan atau dibatasi hanya 15 menit untuk menjawabnya, dimana siswa tidak diperkenankan untuk melihat jawaban dari teman sekelasnya. Kami melakukan penelitian di SMP Negeri 30 Muaro Jambi dan mengambil subjek kelas VIII C dan IX A. Dengan jumlah siswa VIII C 19 orang dan kelas IX A 25 orang dengan jumlah total siswa kelas VII sampai kelas IX adalah 222 orang.

HASIL

\begin{tabular}{|c|c|c|c|c|c|}
\hline $\begin{array}{c}\text { Jumlah } \\
\text { Nilai }\end{array}$ & Rata-Rata & $\begin{array}{c}\text { Nilai } \\
\text { Maksimum }\end{array}$ & $\begin{array}{c}\text { Nilai } \\
\text { Minimum }\end{array}$ & Median & $\begin{array}{c}\text { Standar } \\
\text { Deviasi }\end{array}$ \\
\hline 1509 & 79 & 89 & 65 & 80 & 6,1 \\
\hline 1638 & 78 & 90 & 66 & 79 & 6,8 \\
\hline
\end{tabular}

184 BRILIANT: Jurnal Riset dan Konseptual Volume 4 Nomor 2, Mei 2019 
Hasil yang didapat setelah melakukan penelitian kami mendapatkan bahwa hampir kebanyakan seluruh siswa baik kelas VII C dan IX A memiliki tingkat karakter gemar membaca yang cukup tinggi. Dari data yang kami peroleh selanjutnya kami mengolah data dengan mencari nilai rata-rata atau mean, nilai data tengah atau median, nilai maksimun, nilai minimum, dan standar deviasinya. Didapatkan bahwa nilai rata- rata siswa kelas VII C adalah 79 sedangkan nilai rata-rata kelas IX A adalah 78. Nilai maksimum dari kelas VII C adalah 89 sedangkan kelas IX A 90. Median dari kelas VII C sebesar 80 dan kelas IX A 79. Nilai standar deviasi kelas V11 C adalah 6,11 dan kelas IX A 6,8. Sedangkan nilai minimum kelas VII C adalah 65 dan kelas IX A adalah 66.

\section{Hasil uji normalitas}

Hasil dari uji normalitas menggunakan kolmogorov semirnov terhadap karakter gemar membaca kelas VII C dan kelas IX A. Kelas VII C dan kelas IX A memiliki nilai probabilitas signifikasi lebih dari 0.05 maka dengan ini data berdistribusi normal.

\section{Hasil uji homogenitas}

Hasil uji homogenitas menggunakan Shapuro-wilk terhadap karakter gemar membaca siswa kelas VIIc dan IX A. Kedua kelas memiliki nilai probabilitas baik kelas VIIC dan kelas IX A adalah lebih dari 0,05 maka berdistribusi normal.

\section{PEMBAHASAN}

Pengetahuan didapatkan apabila banyaknya kegiatan membaca. Semakin banyak membaca wawasan yang dimiliki sesorang akan semakin bertambah. Selain membaca menambah wawasan membaca juga merupakan salah satu cara kita dapat menulis. Menurut Abdul Rahman Saleh (2006: 46) beliau menyatakan bahwa kebanyakan siswa SMP tidak menyukai kegiatan menulis karena menurutnya siswa SMP kebanyakan tidak SMP tidak banyak membaca. Hal ini membuktikan bahwa membaca merupakan bekal utama dari segala sesuatu dalam kegiatan pembelajaran baik disekolah maupun di lingkungan masyarakat. Tempat di mana siswa melakukan kegiatan membaca biasanya juga mempengaruhi minat baca siswa. Siswa biasanya cenderung lebih suka membaca dengan lingkungan yang membuat mereka merasa nyaman saat membacanya. Ada siswa yang lebih suka membaca didalam ruang kelas dan juga ada yang lebih suka membaca buku di dalam perpustakaan. Perbedaan siswa tersebut merupakan hal yang wajar, dikarenakan cara belajar siswa setiap orangnya berbeda-beda. Seperti yang disampaikan Rahadian, dkk (2014 : 30) bahwasanya perpustakan tidak hanya sebagai tempat membaca melainkan perpustakan juga dapatmenjadi tempat menumbuhkan atau mengembangkan bakat kemmampuan yang dimilikinya. Dengan lokasi yang nyaman di dalam perpustakaan akan membuat siswa lebih merasa nyaman untuk membaca.

Semakin berkembangnya media massa saat ini informasi yang tadinya susah didapatkan saat ini dengan mudah dapat kita cari. Faktor ini mempengaruhi pola sikap siswa dalam hal membaca. Siswa yang tidak dapat melawan arus media masa akan membuat siswa tersebut memiliki rasa membaca yang kurang dan memnyebabkan siswa menjadi malas. Menurut Yetti (2009:18) mengungkapkan bahwa banyak sekali keluhan-keluhan membaca anak karena adanya media 
massa. Siswa lebih memilih hal yang mudah didapatkan dengan cara yang mudah dibandinhgkan dengan cara yang susah. Media masa dapat membantu siswa memperoleh informasi atau hal yang hendak ingin dicari, Ketika siswa diberi sebuah tugas kebanyakan siswa lebih mencari jawabannya menggunakan telepon dibandingkan membaca yang ada di dalam buku. Kegiatan seperti ini lama kelamaan akan menjadi kebiasaan yang membuat kegiatan membaca buku akan semakin berkurang karena telah terganti dengan adanya media masa.

Kegiatan membaca siswa saat ini makin lama makin keliatan menurun. Dikarenakan bebagai factor yang menjadikan siswa lebih suka bermaslas-malasan saat dirinya disuruh untuk membaca sebuah buku. Menurut Suryaman (2015 : 174) mengatakan bahwa minat baca siswa Indonesia berada pada titik yang rendah dibandingkan dengan negara-negara lain. Peristiwa ini tentu merupakan hal yang seharusnya diperhatikan. Salah satu yang menyebabkan siswa menjadi malas akan membaca adalah adanya sebuah telepon yang saat ini kebanyakan sekolah memperbolehkan membawa sebuah telepon. Ketika siswa membawa sebuah telepon genggam perhatian siswa hanya fokus pada telepon yang dia punya malah tidak memperhatikan pada saat proses pembelajaran. Di sela-sela istirahat yang tadinya dapat di manfaatkan siswa untuk membaca sebuah buku malah dihabiskan dengan memainkan telepon yang digenggamnya. Siswa lebih suka membaca informasi melalui telepon dibandingkan sebuah buku. Dengan telepon siswa dapat juga memberikan dampak positif dimana siswa lebih dapat mancari informasi yang lebih luas yang tidak ada di buku. Namun perlu diingat bahwa telepon digunakan untuk membantu siswa mendapatkan informasi yang nantinya siswa harus membaca informasi tersebut.

Gemar membaca yang dimiliki siswa tentu merupakan hal yang sangat menentukan apakah siswa tersebut dapat menerima informasi pada saat jam pelajaran. Menurut Darmaji (2015 : 226) cara belajar siswa sangat berbeda beda. Artinya disini bahwa seiap siswa memiliki cara pandang belajar yang berbedabeda ada siswa yang cara membacanya lebih suka bersantai ada juga yang membaca dengan suasana yang khusus atau pada waktu tertentu saja. Didalam membaca tentu siswa akan lebih mudah memahami materi yang belum disampaikan kepada guru. Karena didalam fikiran siswa akan muncul rasa ingin tau yang timbul pertanyaan di benaknya. Pada saat itu siswa menjadi termotivasi untuk mengetahui informasi atau materi pembelajaran yang akan disampaikan oleh guru atau pengajar. Menurut Rahardja (2004: 8), beliau menjelaskan bahwa motivasi merupakan dorongan yang timbul dari diri seseorang, untuk berbuat sesuatu. Pada saat mengajar sebaiknya guru memberikan motivasi agar siswanya cenderung semangat buat membaca buku baik materi pelajara maupun bahan bacaan yang lainnya.

Tingkat kesukaan atau gemar membaca siswa SMP 30 Muaro Jambi ini terbilang cukup tinggi. Kebanyakan siswa lebih semangat dalam membaca buku dibanduingkan bosan akan membaca buku. Namun dipilihan jawaban yang lain kebanyakan siswa baik kelas VII C dan IX A tidak bisa meluangkan waktu libur mereka untuk membaca buku. Hal ini tidak dikarenakan siswa cenderung lebih suka bermain dibandingkan membaca ketika hari libur. Padahal seharusnya ketika siswa memanfaatkan hari libur mereka untuk membaca buku mereka akan memiliki pengetahuan yang tidak selalu didapatkan pada saat jam pelajaran disekolah. Dengan meluangkan waktu libur siswa sebenarnya dapar mluangakan

186 BRILIANT: Jurnal Riset dan Konseptual Volume 4 Nomor 2, Mei 2019 
untuk membaca buku yang tidak berkaitan dengan materi pembelajaran disekolah. Di sini siswa dapat membaca buku yang lain seperti halnya buku cerita, novel, majalah, koran dan lain-lain. Dari hasil penelitian juga didapatkan siswa tidak terlalu menyukai buku yang terdapat di perpustakaan. Hal ini didorong kebanyakan siswa lebih menyukai buku yang berbau hiburan dan tidak memiliki materi yang membuatnya harus berfikir keras untuk memahaminya.

Dari rata-rata yang didapatkan dari kelas VII C terlihat kebanyakan dari siswanya memiliki tingkat gemar membaca cukup tinggi yaitu 79 sedangkan pada kelas IX A mendapatkan rata-rata 78. Dengan jumlah siswa kelas VII C sebanyak 19 orang mengindikasikan bahwa siswa kelas VII C dapat di simpulkan cukup tinggi tingkat gemar membacanya. Sedangkan pada kelas IX A dengan jumlah siswa mencapai 21 orang dapat juga diindikasikan bahwa siswa kelas IX cukup tinggi tingkat gemar membacanya dengan persentase kehadiran dari kedua kelas adalah $100 \%$. Nilai dari median kedua kelas yaitu 80 dan 79 . Sedangkan nilai standar deviasinya mendapatkan hasil 6,11 dan 6,8.

Kemudian data selanjutnya kami uji menggunakan SPSS untuk mengetahui apakah data yuang telah kami telitinormal atau masih terdapat kesalahan atau tidak. Kami melakukannya dengan menggunakan uji Normalitas dan uji homogenitas. Dimana uji normalitas dari kelas ViiC dan kelas IX yeng telah kami lakukan diperoleh bahwa datanya berdistribusi normal. Dengan nilai data kedua kelas menunjukan lebih dari 0,05. Uji kedua yaitu uji homogenitas di mana didapatkan hasil baik keloas VII C dan IX A mendapatkan hasil bahwa keduanya berdistribusi normal dan melebihi 0,05 .

\section{KESIMPULAN}

Berdasarkan data yang sudah kami bahas dapat disimpulkan bahwa meningkatkan gemar membaca merupakan suatu hal yang patut diperhatikan pada siswa. Dengan adanya rasa gemar membaca akan membuat siswa lebih paham akan materi pembelajaran yang belum dipelajari sebelumnya. Motivasi salahsatunya merupakan cara agar terciptanya rasa ingin membaca terhadap siswa. Pada siswa SMP Negeri 30 Muaro Jambi 9 tingkat gemar membacanya khususnya kelas VII C dan IX A cukup tinggi. Siswa cenderung suka membaca bacaan yang membuat mereka tidak terlalu menguras pikiran. Jadi siswa SMP Negeri 30 Muaro Jambi rata-rata menyukai bacaan yang tidak berkaitan dengan materi pembelajaran dikelas. Agar siswa dapat memiliki karakter gemar membaca mereka harus memiliki sikap motivasi di dalam pikirannya. Berikut merupakan data hasil penelitian dengan nilai kami bulatkan.

\section{SARAN}

Gemar membaca perlu asanya peningkatan dari diri para siswa. Untuk itu sebaiknya siswa lebih memotivasi dirinya agar terciptanya rasa ingin membaca yang tinggi. Karena dengan banyak membaca siswa akan semakin banyak memperoleh informasi baik yang berkaitan dengan pembelajaran di kelas maupun yang tidak berkaitan dengan pembelajaran. Dan juga sebaiknya sekolah juga ikut andil dalam meningkatkan rasa ingin membaca siswa. Seperti guru mrmberikan pengarahan atau saran terus menerus untuk siswa agar siswa paham akan pentingnya rasa ingin membaca merupakan suatu hal yang sangat penting bagi siswa itu sendiri. Orangtua juga merupakan pengaruh terbesar siswa agar siswa 
atau anak putrinya memiliki rasa ingin membaca yang tinggi. Orangtua sebaiknya menuntun atau menasehati ataupun memberikan fasilitas baik itu buku pembelajaran maupun buku non pembelajaran. Pemerintah merupakan aktor yang sangat penting dalam meningkatkan kegiatan gemar membaca siswa. Sebaiknya pemerintah menerapkan kebijakannya untuk meningkatkan minat baca siswa.

\section{DAFTAR RUJUKAN}

Sasono, Adi. et al.1998. Solusi Islam Atas Problematika Umat (Ekonomi, Pendidikan dan Dakwah). Jakarta: GEMA INSANI PRESS

Nur Pajr, M. Hidayat, Dwi Agus Kurniawan. Pengembangan E-Modul Fisika berbasis Pendekatan Saintifik Pada Materi Rangkaian Listrik untuk Siswa SMP Kelas IX. Jurnal FKIP Universitas Jambi

Nur Aeni, Ani. 2014. Pendidikan Karakter untuk SiswaSD dalam Prepektif Islam. Jurnal Pendidikan Mimbar Sekolah dasar vol. 1 No. 1

Halidjah, Siti. 2011. Pemberian Motivasi untuk Meningkatkan Kegiatan Membaca Siswa Sekolah Dasar. Jurnal Cakrawala Kependidikan. Vol. 9. No. 1

Muhammad Reyza Arief Taqwa, Astalini,darmaji. 2015. Hubungan Gaya Belajar Visual, Auditorial, dan Kinestetik dengan Hasil Belajar Siswa pada Materi Dinamika Rotasi dan Kesetimbangan Benda Tegar Kelas XI IPA SMAN SE-KOTA JAMBI. Jurnal Proseding Seminar Nasional Sains dan PendidikanSains.

Rahman Saleh, Abdul.2006. Peranan Teknologi Informasi dalam Meningkatkan Kegemaran Membaca dan Menulis Masyarakat. Jurnal Pustakawan Indonesia vol. 6 no. 1

Galint Rahardian, Rohanda, Rully Khairul Anwar. 2014. Peranan Perpustakaan Sekolah dalam Meningkatkan Budaya gemar Membaca. Jurnal kajian Informasi dan Perpustakaan. Vol.2. No. 1

Yetti, Rivda. 2009. Pengaruh Keterlibatan Orangtua terhadap Minat Membaca Anak Ditinjau dari Pendekatan Stres Lingkungan. Jurnal Ilmiah Ilmu Pendidikan. Vol. 9. No.1

Suryaman, Maman. 2015. Analisis Hasil Belajar Peserta Didik dalam Literasi Membaca Melalui Studi Internasional (PIRLS) 2011. Jurnal LITERA. Vol. 14. No. 1

Safitri, Nurul. 2013. Korelasi antara Minat Membaca dengan Motivasi belajar Siswa Kelas V SDN 03 Pontianak Selatan. Artikel Penelitian Fakultas keguruan dan Ilmu Pendidikan Universitas Tanjungpura.

Sudrajat, Aajat. 2011. Mengapa Pendidikan Karakter?. Jurnal Pendidikan Karakter. No. 1 